\title{
Selectivities at Work: Climate Concerns in the Midst of Corporatist Interests. The Case of Austria
}

\author{
Ulrich Brand ${ }^{1}$, Adam Pawloff ${ }^{1,2}$ \\ ${ }^{1}$ Institute of Political Science, University of Vienna, Vienna, Austria \\ ${ }^{2}$ Department of Global Change and Sustainability, University of Natural Resources and Life Sciences, Vienna, Austria \\ Email: ulrich.brand@univie.ac.at, adam.pawloff@boku.ac.at
}

Received 29 January 2014; revised 28 February 2014; accepted 21 March 2014

Copyright (C) 2014 by authors and Scientific Research Publishing Inc.

This work is licensed under the Creative Commons Attribution International License (CC BY). http://creativecommons.org/licenses/by/4.0/

(c) (†) Open Access

\begin{abstract}
Despite legally binding greenhouse gas emission reduction targets and good pre-conditions for progressive climate action, emissions in Austria are on the rise. This article explores the reasons why climate change policy is so ineffective in Austria. We show that the social partnership has contributed significantly to the standstill in renewable energy production and the rejection of more ambitious reduction targets concerning greenhouse gas emissions, and consider the role of experts and expertise in climate change policies. The ineffectiveness of climate policy in Austria is largely due to corporatist actors who often act like an ex-ante filter or selective mechanism for what is politically acceptable or possible and what is not. Climate change is for the most part successfully kept off the political agenda and (climate sceptical) politicization does not take place. Insights from the literature on corporatism are enhanced by the concepts of strategic and epistemic selectivity to analyse not only access to the state terrain but also the domination of specific knowledge forms, problem perceptions, and narratives over others.
\end{abstract}

\section{Keywords}

Climate Policy, Corporatism, Social Partnership, EU Climate Targets, Renewable Energy Policy, Strategic Selectivities

\section{Introduction}

For over two decades now, statements of political commitment to tackling the challenge of climate change abound. On the global level, the UN Framework Convention on Climate Change was formed in 1992. In 1997 
the Kyoto Protocol was signed, with binding emissions targets for the EU and other industrialised nations.

Austria itself has a rich history of environmental action, is one of the wealthiest countries in the world, it has efficiently producing industry and a comparatively high level of renewable energy production, all-in-all good preconditions for progressive climate action.

Despite this, 15 years after the Kyoto Protocol was signed emissions in Austria are still high. In 2011, emissions of greenhouse gases in Austria stood at 82.8 million tons of $\mathrm{CO}_{2}$-equivalents, $6 \%$ over 1990 levels [1]. The Austrian target under the Kyoto Protocol (as negotiated under the EU burden sharing agreement) however, is a reduction of $13 \%$ for the years 2008-2012 with respect to 1990 levels (whilst the EU as a whole has overachieved on its Kyoto target [2]).

This article explores the reasons why and how climate change policies take place so unevenly in different fields by focusing on those areas which lag behind. Whilst emissions have been reduced in certain sectors, emissions from transport, industry and energy production, including electricity (the three largest sectoral emitters, responsible for $73 \%$ of total emissions) have all risen [1]. Motorized individual transportation continues to receive privileges: commuter tax allowance ${ }^{1}$ which encourages commuting by automobile is regularly increased and Austria has one of the lowest rates of taxation on petroleum in Europe. Emissions certificates to energy producers and industry in the framework of the EU emissions trading system (ETS) have been persistently overallocated (although this trend has been amplified by the economic and financial crisis in recent years) [3] and in the framework of renewable energy, following restrictive legislation in 2006, renewable energy production came to a standstill for close to five years.

Focusing on renewable energy production, climate targets and expertise relating to the formulation of climate policy, specifically emissions trading, we want to understand better why and how a general fall-back has taken place in a country with high levels of consciousness and good conditions.

We show that in important policy fields the historical (post WW II) constellation of the social partnership in Austria and the consensus orientated style of decision making is key to understand the lagging behind of Austrian climate policy. The social partnership has evolved and functioned quite well concerning the stabilization of class relations, especially the "white male bread-winner" model on the wage-earner side. It created political stability and made quite effective crisis policies possible in many fields. However, it is difficult to integrate environmental concerns within this constellation, which go beyond the perspective of a partial ecological modernization of capitalism or dominant understandings of sustainable development or, more recently, strategies towards a green economy [4]-[6]. This is the reason why effective climate policy, despite its high politicization, is precluded from the political agenda and, therefore, the social partnership has contributed significantly to the standstill in climate policy in Austria. This in itself is not an extraordinary argument. But we seek to show how this exclusion or downplaying of climate change politics works. For this, we focus on the specific political structure in Austria, in particular the corporatist structures of agenda-setting, interest and policy formulation and decision-making as well as its strategic and epistemic selectivities. Given the context of the research we present here, this article is a product of a larger research project on climate politics in Austria with a special focus on climate sceptics, and we can also show that, in contrast to the United States or the UK [7]-[11] and to a lesser extent Germany [12] [13], climate scepticism in Austria does not require a similar level of politicization but can instead refer to corporatist decision-making structures, as a means of hindering or watering-down effective climate policy ${ }^{2}$.

The paper is organized as follows: After some theoretical considerations on corporatism and selectivity we outline briefly corporatist decision-making structures in Austria. Then we will show that despite its relative success in economic and social policy, corporatism poses specific problems when it comes to getting new issues like climate change and related policies onto the political agenda and into the decision-making process. This is shown (a) in the field of renewable energy policies, (b) with respect to and (c) by considering the role of experts and expertise in climate change policies. Beside our insights from empirical research we aim to add to the literature the argument that research on corporatism can benefit from the concept of strategic and epistemic selectivity, which is developed in critical state theory.

\footnotetext{
${ }^{1}$ (German: Pendlerpauschale).

${ }^{2}$ This article is a product of a larger research project on climate politics in Austria with a special focus on climate sceptics. We present here some results of the political science part of the project. The project entitled "Contrarians - their role in the debate on climate change (global warming) and their influence on the Austrian policy making process” is supported with funds from the Climate and Energy Fund and implemented in line with the ACRP program.
} 
We do not argue that pluralist market economies are more effective concerning climate change policies. But we argue that problems of climate policies cannot deny the relative inertia of corporatist structures (which secures policy results on those issues which are part of them).

\section{Corporatism and Strategic/Epistemic Selectivities}

When comparing the role and dominance of interest groups across countries, differences can be seen as a scale or continuum, ranging from pluralism (e.g. the US with no peak associations) to a mixture of pluralism and corporatism (e.g. New Zealand or Japan) to neo-corporatist countries with a few dominant associations (e.g. Austria and Scandinavian countries) [14]. The latter is close to the type of development which is called "coordinated market economies" in the neo-institutionalist literature on Varieties of Capitalism with its focus on firms [15].

On the whole, corporatism, or neo-corporatism (as opposed to the historical term of state corporatism), as a system of interest mediation between government, labour and business interests with a few peak interest organisations that dominate their respective sectors [14] [16] as it exists in Scandinavian countries or Austria has traditionally focused on social and labour policy. However since the 1980's, "new forms of neo-corporatist decision making in the post industrial policy areas of education, health care, welfare and environmentalism" [17] have emerged.

In fact, Colin Crouch's measure of "generalized political exchange" which is an integral part of corporatism and a central indicator in e.g. Siaroff's comparison of corporatism in 24 industrialized states or in discussions of the concept of corporatism e.g. in Molina and Rhodes, defined as a "dense web of interactions binding together a small number of actors" [18] describes the situation in Austria quite aptly and broadens the idea of corporatism "from the labour market or industrial relations to policy-making processes in general" [17]. However, a simple insight should be remembered. "Governments cannot govern without or even against the consensus of giant interest organisations, but can only execute their common (!) will” [19]. And it is quite obvious after decades of environmental policy that environmental issues do not have such a political weight as other policy areas have.

The level of corporatism in a country can also be analysed along two dimensions, one showing the patterns of concertation, the other the level of integration of social partners in decision making. The level of integration, ranges from consultation, giving associations access to information, to integration, giving "real influence over policy design" [17].

We would like to enhance insights from the literature on corporatism with the concepts of strategic and epistemic selectivity with which not only access to the state terrain is analysed but how certain policy priorities are inscribed within the state. We can broaden a perspective on corporatism by focusing not exclusively on the interests and political strategies of particular actors but also by considering the state structure and its selectivity.

A starting point is the theoretical idea that "the success of influence exertion is structurally imbedded (i.e. in the systematic exclusion of all opposed interests)"3 [20]. The selectivity referred to here, describes a sorting process based upon institutionalized rules of inclusion and exclusion. For an operationalization of this concept, one needs to determine what is being excluded, i.e. which "non-events" are taking place because every decision excludes other decisions. Offe describes different types of non-events. On the one hand, there are accidental nonevents. On the other hand, and the focus of our research, systemic non-events arise directly from the organizational structure and processes of the political system and cannot be explained without making reference hereto [20]. The concept of selectivity can thus be defined as the "non-coincidental (i.e. systematic) restriction of a space of possibility" [20].

Bob Jessop enhanced the concept of structural selectivity coined by Offe towards a "strategic-relational perspective" which starts with the following assumption: "Particular forms of state privilege some strategies over others, privilege the access of some forces over others, some interests over others, some time horizons over others, some coalition possibilities over others. A given type of state, a given state form, a given form of regime, will be more accessible to some forces than others according to the strategies they adopt to gain state power.” [21].

In this sense, the state is neither an "autonomous" actor nor a collection of "neutral" institutions but "a relationship of forces, or more precisely the material condensation of such a relationship" [22]. Understanding the state as a materially condensed social relation means that it also constitutes a terrain of contestation which is asymmetrically structured among different forces (i.e. the representatives of capital and labour) and it is more

\footnotetext{
${ }^{3}$ This and all further citations taken from German language literature have been translated from the German original.
} 
open to deal with those problems and interests which are historically constituted and strong. With respect to societal-nature relations it can be argued that the state first secures the dominant norms of production, distribution, and consumption and, at the same time, emerging socio-ecological conflicts are fought out under conditions which are also created or at least heavily influenced by the state. It is not by chance that the manifold social conflicts, which arise out of the ecological crisis, are converted into political conflicts. The conflicting actors pursue their strategies in alliances with state personnel and under specific rules and conditions, which were previously developed in other struggles where societal actors were asymmetrically involved (such as national environmental laws or the Millennium Ecosystem Assessment). Therefore, they have no equal access to the state but are confronted with specific selectivities [21] [23]. In the words of Markus Wissen, the state is a conflict terrain but the "chances to gain access to, and successfully articulate interests in, this terrain (...) are very unequally distributed” [24].

Another insight of critical state theory is that the state with its selectivities stabilizes and modifies the balance of forces among societal and political actors [25] as well as societal orientations and discourses. This is particularly true for corporatist political structures where certain actors have a privileged role, i.e. to be acknowledged actors for collective bargaining and/or to receive their financial basis through their recognition by the state ${ }^{4}$. Insofar, the state gives specific constellations of forces and societal orientations certain durability via bureaucratic, legal, financial, epistemic, or discursive means. From this perspective, subaltern forces and actors as well as non-dominant orientations are inscribed into the state, albeit asymmetrically in relation to dominant or even hegemonic forces and orientations. Additionally, Poulantzas argued that the state is not just a passive receiver but it marks out the fields of societal relations like the division of labour and class relations as well as the fields to fight out conflicts [26].

In order to understand the role of expertise, we would like to introduce briefly the concept of epistemic selectivities [27] [28]. The notion of epistemic selectivities differs from the concept of epistemic communities [29] [30] insofar as it builds on a specific understanding of the relation between structure and agency taking into account the notion of discursive power and hegemony. The concept takes into account patterns of selectivity leading to the domination of specific knowledge forms, problem perceptions, and narratives over others. It is also based on the assumption that political institutions are material condensations of societal power relations and discourses and that, at the same time, they underlie, form, and reproduce epistemic selectivities as a crucial political mode to promote certain scientific and political self-evidence. The concept goes beyond the selectivity within a specific context of decision-making and addresses the hegemonic account inherent in the production and re-production of knowledge, problem perceptions, and narratives regarding specific things to be governed in their socio-economic, political and cultural context. We shall argue that it is self-evident today that climate change policies cannot affect the competitiveness of a national economy and that the mode of production and living is not up for disposal. Therefore, the dominant societal knowledge about environmental policies is that they should take place, if any, within the "corridor" of ecological modernization [4].

\section{Corporatism in Austria: Social Partnership}

Siaroff analysed 23 different rankings of corporatism and Austria was given the top ranking out of all countries in all 23 rankings making Austria something like the model type of corporatism [14]. The corporatist structure in Austria corresponds to (a high level of) integration of the dominant interest groups into the political process, an integration which is historically contingent and, in many cases, can have negative consequences for climate policy, as shall be demonstrated below. From our perspective, it is also important to see how interests are selectively inscribed into the structures of the state.

The historically specific form of corporatism in Austria is called Social Partnership [16] [31]-[34]. The conesquence of this strong cooperation is that decisions are often taken not on the basis of majorities, but on the basis of consensus. The social partnership in Austria is made up of the Austrian Trade Union Federation (ÖGB), and the three chambers: Agriculture, Commerce and Labour. The social partnership is defined as "the pattern of interest representation and interest politics in Austria, between the umbrella organisations of the employers and the employees interest representation organisations, the government and the governmental ministries" [16]. In Austria, membership to either the Chamber of Labour as worker or employee or to the Chamber of Commerce

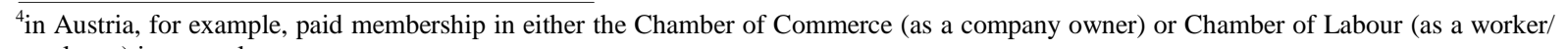
employee) is compulsory. 
as a company is compulsory and subject to a fee [16]. As such, these organisations possess considerable weight both financially and in terms of sheer numbers of members represented, e.g. the Chamber of Labour disposes over much more resources than the trade unions and their federation.

The power of the Federation of Trade Unions comes from centralization. The individual trade unions in Austria do not possess individual legal personality and are dependent upon the Federation for financial support. Consequentially both financial and representational power is, beside the Chamber of Labour, in the hands of the federation, quite apart from the considerable total membership it enjoys [16].

The specific construction of the social partnership does not officially include the Federation of Industry (IV). However, it is de facto a powerful interest representation and enjoys similar privileges [16]. Its influence in Austria comes quite simply from the size of the sector of the economy it represents due to the fact that Austria still has a sizeable industrial basis.

The pattern of decision-making within the framework of the social partnership is characterized by the privileged formal and informal involvement of these umbrella organisations in policy making and implementation on the one hand and on the level of coordination of divergent interests between the organisations on the other [16]. The power of associations in Austria stems from their strong interdependence with political parties, i.e. the Austrian People's Party (ÖVP) and the Social Democratic Party of Austria (SPÖ), parliament and government: "In Austria, these links between the subsystem of interest intermediation and that of government/party politics takes the form of intensive mutual interpenetration. Political parties are incorporated into interest associations, associations into political parties.” [19]. The interdependence of government and interest organisations was also clearly expressed in the interviews conducted in the context of this research: "I think the Minister of Economy has a high level of integrity and is a very competent minister, but who as Minister of Economy, is subject to certain constraints, starting with the Federation of Industry, Chamber of Commerce and so on" (interview with former Social Democratic Secretary on 06.12.2011). The Environment Speaker of the Peoples Party mentioned that: "It is always the question, who is seen as the party. When you look at the position of the Chamber of Labour advising the Chancellor, then you have to assume that carries more weight than if only the Chamber of Labour themselves make a statement” (interview with Peoples Party Environment Speaker on 07.12.2011).

The development of the social partnership, as a multi-dimensional pattern of cooperation and accordance, began in the years immediately following WW II. It was completed in the 1960s where it had reached a standing in Austrian politics which would influence interest politics for decades to come [16], and still does so today. Instrumental in these final developments toward the full institutionalization of the social partnership and symptomatic for the time which followed, were increasing conflicts in the government coalition. These conflicts led to an increase in de-facto out-sourcing of decision-making to the interest representation organisations [16].

Although corporatist politics in Austria began in the context of negotiations on prices and wages, the institutionalisation of such decision-making grew considerably in the decades that followed. For the time period 1971 1987, a study showed that the interest organisations from the social partnership were represented in 223 advisory councils, commissions, committees, conferences, forums and working groups together with government and administrative public officials. This privileged embedding of the social partnership organisations has, on the whole, also been extended to the Federation of Industry [16].

Besides being institutionalized in the political process in the form of various different organisations as described above, the interdependence of interest representation organisations and the two major political parties (and as such parliament and government) goes considerably further. A good example of this is the fact that up until the 1980s, the presidents of the four social partnership interest organisations were also members of parliament. What is demonstrated illustratively for the leadership of these organisations is valid throughout the organisational hierarchy. During the 1970 s, over $50 \%$ of officials from these organisations had some, full- or parttime, function in the Austrian parliament [16]. Ferdinand Karlhofer has gone so far as to say that the interweaving of interest organisation and party functions is a "component part of a historically developed political career model" [35].

Historically, important achievements were gained for the working classes, especially in the male dominated, well-organized and productive industries. After WW II strong state-owned economic sectors in the production, services and finance sectors were created-organized within the Austrian Industry Holding Stock Corporation (ÖIAG), and contributed one quarter to the GNP and made up one fifth of Austrian industrial production in the 1970s [36].

It seems important to note, particularly as the above is a historical and not a current analysis, that recent de- 
velopments have seen changes to corporatism in Austria but this does not seem to have led to significant changes in either the power or influence of the interest organisations from the social partnership.

On the one hand, Austria became a member of the European Union in 1995. As such in many fields policymaking has been transferred to Brussels and accordingly, the large interest representation organisations have also opened EU offices. Although this does mean a loss of terrain nationally, with many issues being decided on the European level, there are still several means of influencing the political process, both through national level policy-making processes and in terms of the Austrian position in the international, i.e. EU context. With regard to decisions on the European level, the respective organisations have turned their attention to EU institutions directly (and have opened Brussels offices) or as part of European interest organisations (e.g. Business Europe) or using existing contacts to individual politicians and ministries to influence the Austrian national position, which in turn has (some) influence on the European decision taken [16].

A second element which is important for the evaluation of weak Austrian climate change policies is the process of Europeanization and globalization of the state. Cerny [37] and Hirsch [38] created the concept of the "competition state" which means that under increasing conditions of international competition public policies are more and more formulated against the background of competitiveness.

A more recent development was the election and subsequent two terms in government of the Freedom Party of Austria (FPÖ) (2000 - 2006, the first of which was cut short). Not being a part of the tight-knit system of ÖVP, SPÖ and the social partnership organisations, the FPÖ was quite keen on and successful in eroding the pattern of consensus politics in the framework of the social partnership, although this has again (at least in part) been reversed since the comeback of the SPÖ-ÖVP coalition (since 2006) [16]. Even if these developments effected long-term changes in the pattern of decision-making, the influence of the individual organisations seems to have remained in place. Formally, their position has even been strengthened in the interim, with the formal acknowledgement of the social partnership in the Austrian constitution in 2008 [39].

This is especially true with respect to the steering of the Austrian economy. Globalization did not lead to convergence but corporatist capitalism or "coordinated market economies" [15] like the Austrian one showed certain path dependencies. Management and owners are more intertwined than in "liberal market economies" and created institutional stabilities during the post-war era and institutional continuity during the opening and privatization of the economy. Korom [36] shows in a detailed analysis that the Austrian political and economic elites were able and willing to maintain, despite two waves of privatization of banks and industry after the year 2000, "national" control over formerly state-owned enterprises. Additional aspects to filter interests are interlocking and multiple directorates of a small economic elite, which is closely connected with political parties. In fact, there was a relative power shift away from some former powerful actors and the rise of the Raiffeisen Group to become a central economic network and player [36]. In this process, ownership remained in large parts national and the economic elite remains well connected.

In our interviews ${ }^{5}$ for the research project we got many details how corporatism works today and how corporatist interests and the balancing of power is inscribed within the state apparatuses itself.

\section{How Do Non-Decisions or Lagging Action in Austrian Climate Policy Occur?}

As has been stated above, climate policy in Austria is or has in many respects lagged behind other European countries (i.e. targets in the framework of the Kyoto Protocol). In the following it shall be argued that this is largely due to the social partnership in Austria, and the specific way in which corporatist actors have privileged access to decision making. Specifically in Austria, certain actors and particular strategies are proving more successful than others in terms of setting the agenda and influencing policies. The Austrian state terrain in particular seems to be strategically and epistemically selective.

Whilst the social partnership organisations were in conflict with one another, i.e. employers and employees organisations on social and distributional policies, or fiscal issues (this being the dominant corporatist pattern), the social partnership often served in bringing about a compromise and prepared the decisions for the formal political process. In the context of environmental policy, more specifically climate policy, these organisations often have similar interests (with the exception of the Chamber of Agriculture on renewable energy), i.e. avoiding

\footnotetext{
${ }^{5}$ In the context of the research 19 interviews were conducted in Austria (November 2011 - May 2012) with representatives from ministries, political parties, interest organisations and associations and NGOs. A further 8 interviews were conducted on the EU level (October 2012) with representatives of the European Commission, the European Parliament, interest organisations and NGOs.
} 
progressive policies as these tend to incur more short term costs for the members of the respective organisations, and as such the balanced mechanism of conflict resolution becomes an unbalanced forceful collection of interests trying to scale down ambition on climate and energy issues. In the words of the German Advisory Council on Global Change (WBGU): "The clear strengths of modern statehood, gaining time through compromise, integration of well-organised interests into the political decision-making process (neo-corporatism) and a wellmeaning balancing of these on the part of a moderating state, have become weaknesses endangering the future viability of post-industrial societies” WBGU [40].

In the following we want to show along three cases how selectivities work. The first one deals with a substantial change in the initially quite successful Austrian Green Electricity Act in 2006 which led to a sharp slowdown in the construction of new installations to produce renewable energy. The second case in point is the contested formulation of Austrian climate policy targets within the EU framework where due to social partnership even the state apparatus, which in other countries insists on more ambitious goals, supported weak targets for Austria. And thirdly, we show that and how interests groups which are part of Austrian social partnership are highly involved in the production of policy relevant knowledge. Of course, given the limited space of a journal article, our arguments are quite condensed. However, as we present results of a larger project we have a lot of evidence that these dynamics are the crucial ones which produced events and non-events.

\subsection{Contested Austrian Renewable Energy Policies}

The role of corporatist organisations with respect to climate change policy in Austria is particularly evident in the case of renewable energy. As opposed to other environmental/climate change issues, the specific constellation with regard to renewable energy may well also be connected to the fact that energy issues are dealt with by the Ministry of Economy (Federal Ministry of Economy, Family and Youth) as opposed to the Ministry of Environment (Federal Ministry of Agriculture, Forestry, Environment and Water Management). As Tálos and Kittel have noted, "the involvement of the organisations in commercial/economic legislative processes is characterized that they as privileged organisations have considerable influence on the subsequent law" [31]. When corporatist organisations work together, rather than opposing one another, as was the case with the 2006 Green Electricity Act (GEA) amendment as will be shown below, then a dominant alliance is formed and their position carries particular weight in the decision-making process.

Renewable energy policy on the national level in European countries can only be understood within the context of EU energy policy. The creation of EU policy on renewable energy was beset by considerable challenges and conflicts, resulting in a lengthy legislative process. Following a Green Paper, "Energy for the Future: Renewable Sources of Energy”, published in 1996, the European Commission released its White Paper, by the same name, in 1997, but did not propose a directive until mid-2000 [41]. The conflicts on targets ranged from the question of the EU target, to the question of the baseline against which renewable energy production (and hence the percentage target in 2010) could be measured.

In Austria this conflict continued for quite some time, as the target stated in the directive, $78.1 \%$ of electricity generation by 2010, related to a total electricity consumption volume (in 2010) of 56 TWh [42]. In 2001 a consensus was reached and the subsequent directive, 2001/77/EC, was enacted with the purpose of promoting "an increase in the contribution of renewable energy sources to electricity production in the internal market for electricity" [42]. The directive itself was amended as part of the European Climate and Energy Package (see chapter 3) resulting in the directive 2009/28/EC, with adjusted targets, which provides the framework for the Austrian amendment in 2011.

In 2002, the directive was translated into Austrian national law in the form of the Green Electricity Act (GEA) ${ }^{6}$. This original version of the law specified a commitment to accept electrical energy from renewable resources, at prices (feed-in tariffs) to be subsequently established by legislative regulation (feed-in tariff regulations). No limits were placed on the total volume of subsidies to be given or the total number of installations able to apply within a given time frame. The costs of the subsidies were raised by a cent-per-kWh charge, levied on end customers by network operators [43].

This initial legislative framework led to significant growth of renewable energy installations (see Figure 1) and as such, rising costs for end customers. In early 2004, around one-and-a-half years after the original law took effect, a number of interest representation groups, the Federation of Industry, Chamber of Commerce,

\footnotetext{
${ }^{6}$ German: Ökostromgesetz.
} 


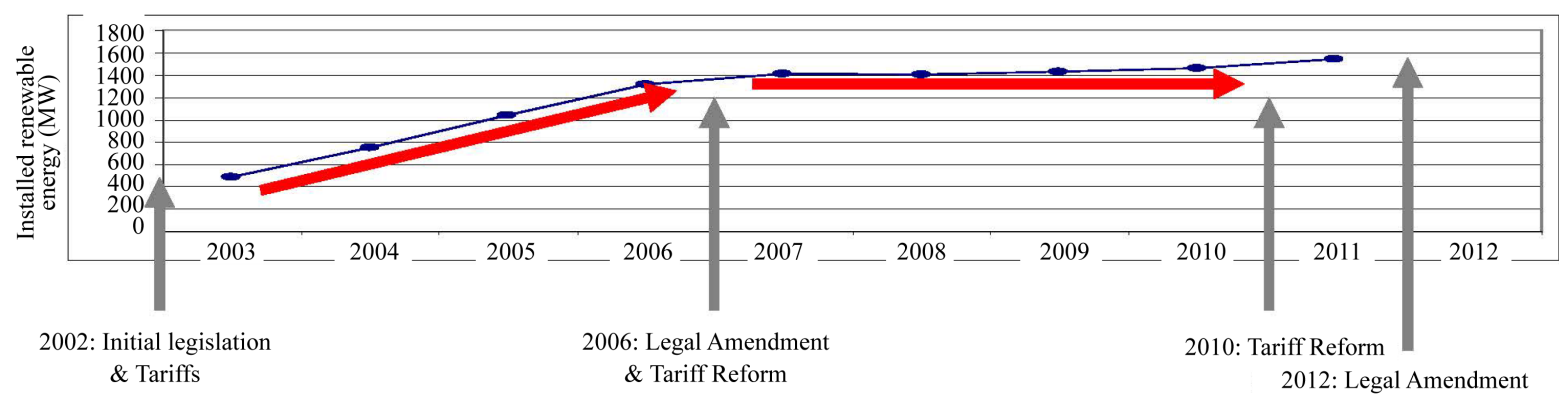

Figure 1. Development of renewable energy legislation and production in Austria (2002-2012) [50].

Chamber of Labour and the Federation of Trade Unions (the so-called “alliance of payers”) made suggestions as to how the law could be amended [44]. The demands of the "alliance of payers" included, but were not limited to:

- Immediate re-regulation of feed-in tariffs

- Considerable lowering of feed-in tariffs

- Declining feed-in tariffs

- Capping the total level of subsidies (Chamber of Commerce 2006: 4)

They argued that "For business, particularly energy intensive industry, a further increase in the energy cost burden would inevitably lead to a halt in investment, relocation of production and endanger international competitiveness with negative impacts on employment and regional development"7 [45].

Of particular significance is not only that an (unlikely) coalition was formed between actors who generally represent conflicting interests, but that the argumentation refers to the larger, "strategic" goals upon which the organisations of the social partnership concur, indeed where these organisations have often found common ground. On the macro-economic front, the social partnership organisations in Austria have found a consensus in pursuing "economic growth, security of employment, stabilization of purchasing power and securing competitiveness" for the economy as a whole, whilst simultaneously pushing their respective agendas [16]. Put another way, "associational co-operation is based on a latent guideline which is that of organising the (capitalist) economic system's rationality into politics. Economising politics (...) establishes orientations on international competitiveness, productivity and economic growth as dominant standards of social rationality and political success (...) and sets up its cultural hegemony over other political goals” [19].

In October 2004, the government bill entered parliament with the main demands of the "alliance of payers" included. Subsidies were capped with additional annual funds limited to 17 mill. Euros for 2005 - 2010, and declining tariffs, another of the central demands, not included in the ministerial draft entered in early 2004, had been incorporated [46]. Another point of note in the course of these events is the comment period ${ }^{8}$ preceding the introduction of the government bill for the amendment of the GEA. This was very unusual in the sense that no comments were received from any members of the "alliance of payers" who are normally amongst the most vocal and very rarely fail to pass comment on bills relevant to them. This would suggest that they were either satisfied by the fact that many of their comments had been taken account of before the entry of the ministerial draft and/or decided to continue to pursue their agenda on a more informal level.

The protagonists of Austrian social partnership were also able to get support from actors who at a first (and also second) glance seem to be "neutral" with regard to the issue in question. One such actor referred to in the course of the interviews conducted, is the electricity market regulatory authority (E-Control), a body that is in principle supposed to be independent. According to one interview partner however, the E-Control was often in favour of rather more restrictive policy (see interview with Federal State representative on 18.11.2011) in relation to renewable energy production. As has been mentioned above, the regulatory authority was one of the actors demanding a cap on renewable energy support in 2006, representing the interests of the members of several

\footnotetext{
${ }^{7}$ It should be noted that the source cited is a member of the Austrian Green Party. The "social partner document" referred to in the power point presentation from the Chamber of Commerce cited below (at that time still "secret") was included as part of press conference documents on $20^{\text {th }}$ of April 2004. The arguments and demands included are corroborated within the power point presentation and in various other documents from the actors in question.

${ }^{8}$ In accordance with the usual parliamentary procedure in Austria of a comment period following the entry of a ministerial draft before the government bill is introduced.
} 
of the "alliance of payers" (see interview with Federal State representative on 18.11.2011). It seems rather odd that a regulator, who self-referentially states that "to act even-handedly in the interests of all market participants, regulators must be politically and financially independent." (E-Control 2012) should represent certain interests. Some light is shed on this situation by the assessment that the regulatory authority and the Ministry of Economy work together closely (see interview with Federal State representative on 18.11.2011) and in turn by the fact that the Ministry is subject to certain constraints (see interview with former Social Democratic Party Secretary on 06.12.2011) by the clientele it serves (see interview with Federal Ministry of Economy, Family and Youth representative on 14.11.2011).

In 2006 the amendment of the GEA was passed. In accordance with the government bill, additional annual funds available for subsidies were capped at 17 million Euros. Subsequently, in line with the provisions of the amendment, a new tariff regulation was passed with considerably lower (and declining) feed-in tariffs, as demanded by the "alliance of payers".

Following this amendment to the legislative framework, renewable energy production stagnated completely for 4 years. For example, in the four years from 2007 until 2010 the average annual additionally installed wind energy capacity averaged 12.7 MW, contrasted with the four years from 2003 until 2006 (immediately following the initial legislation) which averaged 208.3 MW [47]. The stagnation in renewable energy production also led to the fact that Austria did not achieve its EU 2010 renewable energy target of $78.1 \%$ of electricity production, reaching a production level of only $64.7 \%$ [48]. This remained without repercussions however, as the targets in the original directive were revised completely (target year changed to 2020, target levels set according to gross energy consumption) in, and replaced by, the new directive passed in 2009 [49].

The 2006 amendment of the GEA is a very good example for unequal and highly restricted access to the state terrain and the strategic and epistemic selectivities of the Austrian state. Despite considerable opposition from the powerful Austrian Federal States, NGOs, the Green Party, etc. the "alliance of payers" were successful in getting practically all their demands into the final legal text. In light of the above, there are good, plausible reasons for this. On the one hand, the argumentation employed by the organisations fits with the shared conception and dominant paradigm established in Austria over the past decades. On the other hand, the fact that many of the major forces in Austrian politics, forces that generally form part of a delicate balance of power, were united on one side of the debate had the effect that no alternative perspective had any chance of being realized. As the climate policy speaker of Greenpeace noted, "The problem is, that this balancing of interest does not take place in environmental politics. There is no environmental representative in the social partnership" (interview with Greenpeace climate policy speaker on 07.05.2012).

\subsection{Contested Aims of EU Climate Policy Targets}

Another case in point where the positions of a number of peak associations have corresponded to the position of the Austrian federal government and thus illustrates their common agenda, it is assumed here that the Austrian national position is determined in large part by the peak associations ${ }^{9}$, is the Austrian national position on climate targets on the European and UN levels. The issue, which will be discussed here, is the conflict surrounding the common EU emissions reduction target for the year 2020. The commonly agreed, and the currently legally binding, target within the climate and energy package is a reduction of $20 \%$ by 2020 .

In the run-up to the climate and energy package of 2008, the European Council noted in the presidency conclusions of March 2007 that "the European Council endorses an EU objective of a 30\% reduction in greenhouse gas emissions by 2020 compared to 1990 as its contribution to a global and comprehensive agreement for the period beyond 2012, provided that other developed countries commit themselves to comparable emission reductions and economically more advanced developing countries to contributing adequately according to their responsibilities and respective capabilities." [51].

The global and comprehensive agreement failed to materialize at the Copenhagen climate conference (COP 15) in December 2009. Furthermore, industrial production in the EU, and consequentially emissions, declined dramatically in 2009, emissions from the Emissions Trading System (ETS) sector in Austria, for example, dropped by nearly 15\% from 2008 to 2009 [52], as a result of the global financial crisis. These developments prompted the European Commission to publish a communication in May 2010 entitled, "Analysis of options to

\footnotetext{
${ }^{9}$ Direct influence cannot be shown, as the determination of national level positions and their articulation on the European level is almost entirely in-transparent. However, many interviewees confirmed this fact.
} 
move beyond 20\% greenhouse gas emission reductions and assessing the risk of carbon leakage” [53]. Although the Commission's communication made quite clear that "the purpose of this Communication is not to decide now to move to a $30 \%$ target" but rather to "facilitate a more informed debate on the implications of the different levels of ambition, this Communication sets out the result of analysis into the implications of the $20 \%$ and $30 \%$ targets" [53], the publication marked the start of an intense debate. European industry strongly opposed and still opposes a unilateral move to $30 \%$ and voices in the EU Commission, notably Commissioners Tajani and Oettinger [54], oppose any such action.

It should also be noted that subsequent analysis published within the so-called 2050 Roadmap has argued that "if the EU delivers on its current policies, including its commitment to reach $20 \%$ renewables, and achieve $20 \%$ energy efficiency by 2020, this would enable the EU to outperform the current $20 \%$ emission reduction target and achieve a 25\% reduction by 2020.” [55]. The latest figures (for 2011) show that the EU has already reduced its emissions by $18.4 \%$ and as such, is close to achieving the 2020 target several years early [2].

On the day of the release of the communication the Austrian Chamber of Commerce [56], the Federation of Industry [57] and the Electricity Industry [58] all reacted with press releases sharply condemning any unilateral action on the part of European Union. Although no press release or other communication was released to this effect, the employees side of the social partnership, in the form of the Chamber of Labour, also opposed any unilateral increase to the EU target (see interview with Chamber of Labour representative on 04.11.2012). Two weeks later, around the time of the EU Council of the Ministers of Environment meeting on June $11^{\text {th }} 2010$, the Austrian Ministry of Environment sent out three press releases all of which rejected a unilateral increase of EU emission reduction targets, describing them as "back-firing" [59], [translation from German original], "off the table” [60], [translation from German original] and "unwise” [61], [translation from German original]. This position is clearly in conflict with the current government declaration, which explicitly states that, the "federal government supports ambitious climate policy" [62].

In stark contrast to this position, several European countries actively supported and advocated increasing the EU emission reduction target to 30\%. Although business and industry representatives on the European level (e.g. Business Europe or the European Alliance of Energy Intensive Industries) but also in e.g. the UK, with the Confederation of British Industry responding that "in the absence of a globally-binding climate deal, talk of unilaterally raising the EU 2020 target is premature. We believe a unilateral move by the EU could disadvantage manufacturers..." [63], and Germany [64], also criticised and rejected any idea to increase the reduction target, such an increase was supported on the national level in several countries. However, the then environmental ministers of Germany (Norbert Röttgen), UK (Chris Huhne,) and France (Jean-Louis Borloo), met in July 2010 and published a press release entitled " 30 percent less emissions by 2020", clearly stating that a " 20 percent reduction is not enough", particularly in terms of European competitiveness in the low carbon economy of the future [65], [translation from German original].

What is particularly significant about the debate surrounding the issue of the EU reduction targets for 2020 is not the fact that member states have differing positions, that is completely normal, but that that Austria's position was determined by the position of business and industry and other social partnership organisations, whereas Germany, the UK and France all supported raising European ambition despite clear opposition from industry on the European level and in their respective national contexts. These insights were also corroborated in the interview conducted with the representative from the Chamber of Labour who stated that: "There is this discussion whether the EU should reduce its emissions by $20 \%$ or more by 2020. In these discussions, the High-LevelGroup secured the decision to say, that the target can only be increased if the other major industrialised countries also take on binding targets" (interview with Chamber of Labour representative on 04.11.2013). This is in no way to make the suggestion that business and industry and other interest organisations do not have significant influence over policy in these countries in many cases, but illustrating the particularity of the Austrian political system and the influence over the agenda, and indeed influence over the major political parties in general [66], that peak associations have. The overlapping of business and industry and government positions with respect to the issue of EU targets seem further compounded by a joint presentation of a study in April 2011 by the Ministry of Economy the Federal Chancellery, the Chamber of Commerce, the Federation of Industry and the Electricity Industry entitled "Analysis of Options to Move Beyond 20 Percent Greenhouse Gas Emission Reductions. Policy Brief addressing the EC Communication on More Ambitious Greenhouse Gas Reductions.” [67] in which all speakers (representatives of the respective organisations) rejected a unilateral increase of EU emissions targets. 


\subsection{Expertise about "Appropriate" Climate Policies}

The privileged position and access of relevant interest organisations in Austria is also secured via the production of expertise and policy knowledge. In a recent study on the interaction of science and policy in Austrian climate policy, Hermann et. al. have noted that "interest organisations take in a particular and in part ambivalent role at the interface of science and policy" [68]. They are an important source of (selective) scientific and practical knowledge and have multiple informal means of information exchange with political actors. In particular the Chamber of Commerce and the Federation of Industry are seen as particularly influential in this respect [68]. Actors from ministries interviewed in the course of the Hermann et al. study attested representatives of interest associations "profound, comprehensive expertise" [68]. Of particular note in this context, is the fact that interest associations are involved in applied research projects not only as stakeholders, but also as project partners [68].

The consequences of these findings are quite profound. On the one hand, the interests of associations in the social partnership dominate not only the decision making process (as has been demonstrated above) but also play a significant role in the production of knowledge relating to climate policy. On the other hand, the involvement of these actors in knowledge production closely linked to the science-policy interface (i.e. as project partners) leads to interests being translated into (seemingly neutral) expert knowledge, giving it an entirely different significance.

Such processes have also been observed in the context of emissions trading in Austria, in particular the creation the National Allocation Plans (NAP) in the context of the first (2005-2007) and second (2008-2012) trading periods of the EU Emissions Trading System (EU ETS). On the one hand, "environmental NGOs did not really involve themselves in the allocation plan activities. It was a very technical discussion.” (interview with Federal Ministry of Agriculture, Forestry, Environment and Water Management representative on 25.10.2011), leading to a quite one-sided debate on the issue. On the other hand, the ministry representative mentioned, in relation to the decision-making process, that "we have a technical working group in which business representatives sit, also the Chamber of Commerce, the Federation of Industry and the Association of Austrian Energy. And the ministerial representation is in essence the Ministry of Economy. We discussed the details with them.” (interview with Federal Ministry of Agriculture, Forestry, Environment and Water Management representative on 25.10.2011) The draft NAP for the second ETS trading period which Austria submitted to the European Commission, proposed an allocation of 32.8 million certificates per annum [69], which was subsequently decreased by over 2 million certificates by the European Commission. In its decision on the Austrian NAP II, the Commission stated that "the intended total quantity of allowances to be allocated according to the national allocation plan would be inconsistent with achieving Austria's commitment under Decision 2002/358/EC and the Kyoto Protocol.” [70].

What is particularly interesting about the above insights from the Ministry of Environment in relation to the issue of knowledge production is the fact that interest representation organisations participate in a technical working group, a working group to which they are by definition invited as experts and not as (vested) interests. As stated above, when vested interests are communicated in the apparent form of expert knowledge, something usually attributed to the scientific and supposedly interest "neutral" realm, they gain a totally different form of legitimation then they would otherwise have. Interests (which are counterproductive in terms of progressive climate policy) "become" expert knowledge which forms the basis for of so-called "evidence-based" policy making. The particular issue in relation to climate policy is that the balance of forces (employer and employee interests) generally inherent to the social partnership is missing in such a constellation, as is the case with respect to knowledge production here, then the possibility to articulate positions other than the dominant one become extremely limited and are almost bound to fail.

A further case in point in relation to expertise about climate change policy is the Austrian Climate Protection Act $(C P A)^{10}$ passed in 2011. The law has the stated goal of coordinating effective climate protection measures, and distributing the total emissions (according to Austrian EU and international climate targets) across national sectors [71]. The central decision-making body established through the CPA is the "National Climate Protection Committee" (NCPC) whose task it is to "discuss fundamental questions for long-term Austrian climate policy, in particular the creation of climate protection strategies as the basis for distributing total emission across sectors, (...) long-term scenarios for increasing energy efficiency (...) as well as long-term reduction paths toward a lowcarbon economy" [71]. In short, the NCPC will play a central role determining future Austrian climate policy. The other body established through the CPA is the "National Climate Protection Advisory Board" (NCPAB)

\footnotetext{
${ }^{10}$ German: Klimaschutzgesetz.
} 
with advisory functions only.

When the government bill was introduced in June 2011, the proposed membership of the NCPC consisted of representatives from eight federal ministries, the federal chancellery and the nine Austrian federal states. The NCPAB consisted of a whole range of actors including the social partners, science representatives and representatives of three environmental NGOs [71]. The only significant change from the proposed bill to the CPA, passed in October 2011, was the promotion of the four social partners from the NCPAB to the NCPC, i.e. from a purely advisory role to part of the major planning and decision making body for Austrian climate policy. Other actors such as the Austrian EPA as well as science and NGO representatives retained their positions in an advisory function.

Some light was shed on the background to these developments by our interview partner from the Chamber of Labour. "One fear from the business side was that proposals adopted by the climate protection committee, in which the agricultural ministry is the chair, could influence policy design in other ministries. That was a reason why the social partners, we were also open to this suggestion from the business side, strived, successfully, to get a seat in the climate protection committee, the decisive body in the framework of this act." (interview with Chamber of Labour representative on 04.11.2013).

The fundamental shift from an advisory role to a role in which, as has been outlined above, the major strategies in climate policy are discussed and decided upon, lends the social partnership a significantly increased sphere of influence over both the problem definition and the design of solutions in this context. Significant for the production of knowledge on climate policy is the fact that other, alternative (ecological) positions, remain in a purely advisory role.

\section{Conclusions}

This supports one of the major findings of our research project, not the focus of this particular article but we dealt with this aspect as well, which is the following [72]: In Austria, explicitly denying the science of climate change is not necessary because, on the whole, when (supposed) consumer or industrial interests are at stake ecological positions are filtered out of the political process. Ecological interests are represented in parliament, especially by the Green Party, but the parliament is involved at such a late stage in legislation that the main points of conflict have already been clarified (by ministries and corporatist actors). This reduces also the influence of environmental NGOs and public debates.

Austria is an interesting case in point concerning the ineffectiveness of climate policies. Due to their influential position, gained during post-war "consensus-oriented" politics which still predominate the political culture, and multiple points of entry into the policy making process, corporatist actors in Austria often act like an ex-ante filter or selective mechanism for what is politically acceptable/possible and what is not.

Corporatist arrangements do not work as well as they did in the 1950s to 1980s. But they are sufficient enough to hinder effective policies in new issue areas like climate change. They produce various selectivities in the above outlined sense, i.e. as non-coincidental restrictions of possibilities. The problem of effective climate change policies today lies in the fact that even in countries like Austria and Germany with good conditions for effective policies, well developed environmental industries, relatively strong steering capacities of the state, high environmental consciousness, little negative impacts of the current economic crisis, the corridor of ecological modernization seems to be rather narrow. The on-going pre-eminence of orientations at economic growth, international competitiveness and the securing or creation of employment results in a primacy of functional interest organisations over political parties and social partnership over parliamentarianism and government, because they are "its most powerful executives" [19]. The same can be also said for the dominant (party) political forces in the Austrian landscape, the Social Democratic Party and the Peoples Party. Although pursuing opposing agendas on important issues of economic and social equality, these conflicts took and take place within the framework of a dominant, shared paradigm of growth, competition and employment. Such a shared conception clearly has negative consequences for climate change issues as mitigation policy, such as subsidizing renewable energy or imposing costs on polluters through emission trading schemes, incurs costs on economic actors, costs which are rejected on precisely these grounds: such costs hamper economic growth, endanger employment and lower the international competitiveness of Austrian companies (i.e. carbon leakage arguments).

Only in some branches like electrical power production are marginal changes made (from 2005-2011 the per- 
centage of renewables in Austrian electricity production increased from 61.3\% to 64.6\% [48]); in the transport and industry sector is seems difficult. Overall, it does not lead to the required reduction of greenhouse gas emissions (nor to the reduction of the use of resources neither the pressure on ecosystems).

However, from our state theoretical perspective, the "ex-ante filter" does not work independently from the state which is understood as a social relation. Corporatism and the social partners as well as the dominant forms of production, consumption and societal orientations are in a certain way created and stabilized by the state. The state is crucial in defining the terms of how to deal with societal conflicts and it constitutes the terrain to convert those conflicts into political ones or even de-politicise them as non-events. Towards other forces which, for instance, promote more ambitious climate politics the state is strategically and epistemically selective. Therefore, the political stabilization of unsustainable economic and societal practices is not just a question of power but also about the structure and functioning of the state itself.

We wanted to show in this article in detail how corporatism and strategic as well as epistemic selectivities work. The first case study showed that a self-proclaimed "alliance of payers" of actors of Austrian social partnership was able to convert the Green Electricity Act decisively not least due to strategic selectivities of the Austrian state and the reference to a powerful dispositive, i.e. the securing of the production location, international competitiveness and employment. Our second case showed that the Austrian position on overall EU climate targets supported lower targets due to a strong consent among corporatist actors while environmental actors and concerns played little or no role. This led to a situation that even the Ministry of Environment, which is in many other states the most ambitious part of the state concerning climate policies, supported these weak targets. And thirdly, we showed that also a strong epistemic selectivity exists: Corporatist actors do not just represent legitimately vested interests but they are part of the production of knowledge and expertise.

We did not touch upon two aspects which might be helpful to get more insights into lagging climate policies. The deeply inscribed societal practices of producers and consumers or, more broadly speaking, the mode of fossilist-imperial production and living [73] which continues to claim access to global resources and sinks which are seen as unlimited. Ineffective state and climate policy and related selectivities cannot be understood without considering this constellation. And beyond the important dimensions of expertise and epistemic selectivities, questions of dominant discourses and rationalities create the mentioned corridors of the plausible and possible.

In order to overcome this problematic, i.e. unsustainable constellation, one consequence might be to shape the interest structures of corporatist associations and the actors whose immediate interest they represent, i.e. of Austrian entrepreneurs, the owners of assets and of the people who are all materially and mentally inscribed within societal relations which obviously do not take socio-ecological problems like climate change seriously enough. This would go hand in hand with a shaping towards a "greener state" which takes sustainability issues seriously as a complicated but necessary political process. Then, the perception of a very narrow corridor of action, considering a soft ecological modernization as the maximum possible, and rhetorical references to socio-ecological and especially climate issues might be overcome. But this would be topic of another, much needed research project.

\section{Interviews Cited}

Federal Ministry of Agriculture, Forestry, Environment and Water Management representative on 25.10.2011 Chamber of Labour representative on 04.11.2011

Federal Ministry of Economy, Family and Youth representative on 04.11.2011

Federal State representative on 18.11.2011

Former Social Democratic Party Secretary on 06.12.2011

Peoples Party Environment Speaker on 07.12.2011

Greenpeace Climate Policy Speaker on 07.05.2012

\section{References}

[1] Environment Agency Austria (2013) Klimaschutzbericht 2013. Vienna.

[2] European Commission (2013) EU Greenhouse Gas Emissions and Targets. http://ec.europa.eu/clima/policies/g-gas/index_en.htm

[3] Skjærseth, J.B. and Wettestad, J. (2009) The EU Emissions Trading System Revised (Directive 2009/29/EC). In: Skjærseth, J.B. and Wettestad, J., Eds., The New Climate Policies of the European Union. Internal Legislation and Climate Diplomacy, VUBPRESS, Brussels, 65-92. 
[4] Brand, U. (2010) Sustainable Development and Ecological Modernization-The Limits to a Hegemonic Policy Knowledge. Innovation: The European Journal of Social Science Research, 23, 135-152.

http://dx.doi.org/10.1080/13511610.2010.522403

[5] Brand, U. (2012) Green Economy the Next Oxymoron? No Lessons Learned from Failures of Implementing Sustainable Development. GAIA—Ecological Perspectives for Science and Society, 21, 28-32.

[6] Newell, P. (2008) The Political Economy of Global Environmental Governance. Review of International Studies, 34, 507-529. http://dx.doi.org/10.1017/S0260210508008140

[7] Powell, J. (2011) The Inquisition of Climate Science. Columbia University Press, New York.

[8] Oreskes, N. and Conway, E. (2010) Merchants of Doubt. How a Handful of Scientists Obscured the Truth on Issues from Tobacco Smoke to Global Warming. Bloomsbury, New York.

[9] Hoggon, J. (2009) Climate Cover-Up. Greystone, Vancouver.

[10] Boykoff, M.T. and Boykoff, J.M. (2004) Balance as Bias: Global Warming and the US Prestige Press. Global Environmental Change, 14, 125-136. http://dx.doi.org/10.1016/j.gloenvcha.2003.10.001

[11] Poortinga, W., Spence, A., Whitmarsh, L., Capstick, S. and Pidgeon, N.F. (2011) Uncertain Climate: An Investigation into Public Skepticism about Anthropogenic Climate Change. Global Environmental Change, 21, 1015-1024. http://dx.doi.org/10.1016/j.gloenvcha.2011.03.001

[12] Engels, A., Hüther, O., Schäfer, M. and Held, H. (2013) Public Climate-Change Skepticism, Energy Preferences and Political Participation. Global Environmental Change, 23, 1018-1027. http://dx.doi.org/10.1016/j.gloenvcha.2013.05.008

[13] Brunnengräber, A. (2013) Klimaskeptiker in Deutschland und ihr Kampf gegen die Energiewende. Vienna.

[14] Siaroff, A. (1999) Corporatism in 24 Industrial Democracies: Meaning and Measurement. European Journal of Political Research, 36, 175-205. http://dx.doi.org/10.1111/1475-6765.00467

[15] Hall, P. and Soskice, D. (2001) An Introduction to Varieties of Capitalism. In: Hall, P. and Soskice, D., Eds., Varieties of Capitalism. The Institutional Foundations of Comparative Advantage, Oxford University Press, Oxford, 1-68.

[16] Tálos, E. (2008) Sozialpartnerschaft. Ein zentraler politischer Gestaltungsfaktor in der Zweiten Republik. Studienverlag, Innsbruck.

[17] Molina, O. and Rhodes, M. (2002) CORPORATISM: The Past, Present, and Future of a Concept. Annual Review of Political Science, 5, 305-331. http://dx.doi.org/10.1146/annurev.polisci.5.112701.184858

[18] Crouch, C. (1990) Generalized Political Exchange in Industrial Relations in Europe during the Twentieth Century. In: Crouch, C., Ed., Governance and Generalized Exchange: Self-Organizing Policy Networks in Action, Campus Verlag, Franfurt, 69-116.

[19] Marin, B. (1985) Austria-The Paradigm Case of Liberal Corporatism? In: Marin, B., Ed., The Political Economy of Corporatism, St. Martins Press, New York.

[20] Offe, C. (1980) Strukturprobleme des kapitalistischen Staates. Surkamp, Frankfurt am Main.

[21] Jessop, B. (1990) State Theory: Putting the Capitalist State in Its Place. Polity, Cambridge.

[22] Poulantzas, N. (1978) State, Power, Socialism. Verso, London.

[23] Jessop, B. (2007) State Power: A Strategic-Relational Approach. Polity, Cambridge.

[24] Wissen, M. (2011) Gesellschaftliche Naturverhältnisse in der Internationalisierung des Staates. Konflikte um die Räumlichkeit staatlicher Politik und die Kontrolle natürlicher Ressourcen. Westfälisches Dampfboot, Münster.

[25] Demirovic, A. (2007) Demokratie und Herrschaft. Westfälisches Dampfboot, Münster.

[26] Poulantzas, N. (2002) Staatstheorie: Politischer Überbau, Ideologie, Autoritärer Etatismus. VSA, Bad Homburg.

[27] Brand, U. and Vadrot, A. (2013) Epistemic Selectivities and the Valorisation of Nature: The Cases of the Nagoya Protocol and the Intergovernmental Science-Policy Platform for Biodiversity and Ecosystem Services (IPBES). Law, Environment and Development Journal, 9, 202-220.

[28] Vadrot, A. (2014) The Politics of Knowledge and Global Biodiversity. Routledge, London.

[29] Adler, E. and Haas, P.M. (1992) Conclusion: Epistemic Communities, World Order, and the Creation of a Reflective Research Program. International Organization, 46, 367-390.

[30] Haas, P. (2005) Science and International Environmental Governance. In: Haas, P., Ed., Handbook of Global Environmental Politics, Edward Elgar Publisher, Cheltenham, 383-401.

[31] Tálos, E. and Kittel, B. (2001) Gesetzgebung in Österreich. WUV, Vienna.

[32] Lewis, J. (2002) Austria in Historical Perspective: From Civil War to Social Partnership. In: Lewis, J., Ed., Policy Concertation and Social Partnership in Western Europe, Lessons for the Twenty-First Century, Berghahn, Oxford, 19-34. 
[33] Tálos, E. and Kittel, B. (2002) Austria in the 1990s: The Routine of Social Partnership in Question? In: Tálos, E. and Kittel, B., Eds., Policy Concertation and Social Partnership in Western Europe, Lessons for the Twenty-First Century, Berghahn, Oxford, 35-50.

[34] Berger, S. and Compston, H. (2002) Policy Concertation and Social Partnership in Western Europe. Lessons for the Twenty-First Century. Berghahn, Oxford.

[35] Karlhofer, F. (1999) Verbände: Organisation, Mitgliederintegration, Regierbarkeit. In: Karlhofer, F., Ed., Zukunft der Sozialpartnerschaft, Signum, Vienna, 15-46.

[36] Korom, P. (2012) Kein Ende der “Österreich AG”? Über die Beständigkeit eines koordinierten Unternehmensnetzwerkes in Zeiten der Privatisierung und Internationalisierung. Österreichische Zeitschrift für Politikwissenschaft, 41, $141-160$.

[37] Cerny, P. (1990) The Changing Architecture of Politics. Structure, Agency, and the Future of the State. Sage Publications, London and Newbury Park.

[38] Hirsch, J. (1997) Globalization of Capital, Nation-States and Democracy. Studies in Political Economy, 54, 39-58.

[39] Federal Republic of Austria (2008) Änderung des Bundes-Verfassungsgesetzes und Erlassung eines Ersten Bundesverfassungsrechtsbereinigungsgesetzes. BGBl. I Nr. 1/2008.

[40] German Advisory Council on Global Change (WBGU) (2011) World in Transition-A Social Contract for Sustainability. WBGU, Berlin.

[41] Rowlands, I.H. (2005) The European Directive on Renewable Electricity: Conflicts and Compromises. Energy Policy, 33, 965-974. http://dx.doi.org/10.1016/j.enpol.2003.10.019

[42] European Council (2001) Directive 2001/77/EC of the European Parliament and of the Council of 27 September 2001 on the promotion of electricity produced from renewable energy sources in the internal electricity market. ABI L 283/ 33.

[43] Federal Republic of Austria (2002) Ökostromgesetz sowie Änderung des Elektrizitätswirtschafts und—organisationsgesetzes (ElWOG) und das Energieförderungsgesetzes 1979 (EnFG). BGBl I Nr. 149/2002.

[44] Chamber of Commerce (2006) Ökostromgesetz-Novelle. http://portal.wko.at/wk/dok_detail_file.wk?AngID=1\&DocID=557435\&StID=268741

[45] Glawischnig, E. (2004) Grüne zu Geheimpapier der Sozialpartner: Zerschlagung des Ökostromfördermodells geplant [Press Conference Documents]. http://www.auge.or.at/_TCgi_Images/auge/20040930221249_sozialpartner_1.pdf

[46] Federal Government of Austria (2004) Regierungsvorlage. Bundesgesetz, mit dem das Ökostromgesetz, das Elektrizitätswirtschafts und -organisationsgesetz und das Energie-Regulierungsbehördengesetz geändert werden [Government Bill].

[47] Austrian Wind Energy Association (2013) Windkraft in Österreich, Europa und Weltweit. http://www.igwindkraft.at/?xmlval ID KEY[0]=1047

[48] Statistics Austria (2013) Gesamtenergiebilanz Österreich 1970 bis 2011 (Detailinformation). http://www.statistik.at/web_de/statistiken/energie_und_umwelt/energie/energiebilanzen/index.html

[49] European Council (2009) Directive 2009/28/EC of the European Parliament and of the Council of 23 April 2009 on the promotion of the use of energy from renewable sources and amending and subsequently repealing Directives 2001/77/ EC and 2003/30/EC. ABI L 140/16.

[50] E-Control (2012) Ökostrombericht 2012. Vienna.

[51] Council of the European Union (2007) Brussels European Council 8/9 March 2007. Presidency Conclusions. Brussels.

[52] Environment Agency Austria (2011) Klimaschutzbericht 2011. Vienna.

[53] European Commission (2010) Communication from the Commission to the European Parliament, the Council, the European Economic and Social Committee and the Committee of the Regions. Analysis of Options to Move Beyond 20\% Greenhouse Gas Emission Reductions and Assessing the Risk of Carbon Leakage. Brussels.

[54] Harvey, F. (2011) Hopes of 30\% Cut in Greenhouse Emissions Dashed. EU Energy Chief Fears Target Would Lead to a Too-Fast Process of De-Industrialisation as Compared to Current 20\%. The Guardian, London.

[55] European Commission (2011) Communication from the Commission to the European Parliament, the Council, the European Economic and Social Committee of the Regions. A Roadmap for Moving to a Competitive Low Carbon Economy in 2050. Brussels.

[56] Chamber of Commerce (2010) Leitl fordert “Klimaschutz mit Maß und Ziel ohne neue Belastungen für Unternehmen” [Press Release].

[57] Federation of Industry (2010) Industrie weist weitere unilaterale EU-Schritte im Klima-Bereich schärfstens zurück [Press Release]. 
[58] Austrian Electricity Industry (2010) Oesterreichs Energie: Einseitige Emissionsreduktion der EU nicht zielführend [Press Release].

[59] Federal Ministry of Agriculture Forestry Environment and Water (2010) Berlakovich beim EU-Umweltministerrat: EU muss weltweit Klimaverbündete finden [Press Release].

[60] Federal Ministry of Agriculture Forestry Environment and Water (2010) Berlakovich: 30\% EU-CO ${ }_{2}$-Reduktionsziel derzeit keine Option [Press release].

[61] Federal Ministry of Agriculture Forestry Environment and Water (2010) EU-Umweltminister beraten über ehrgeizigere Klimaziele [Press Release]

[62] Federal Government of Austria (2008) Regierungsprogramm 2008-2013. Gemeinsam für Österreich. Vienna.

[63] Euractive (2010) Hedegaard Backtracks on EU Climate Goals [Press Release].

[64] German Federation of Industry (2010) BDI lehnt einseitige Erhöhung des EU-Klimaziels ab [Press Release].

[65] German Federal Ministry for the Environment Nature Conservation and Nuclear Safety (2010) 30 Prozent weniger Emissionen bis 2020 [Press Release].

[66] Sickinger, H. (2009) Politikfinanzierung in Österreich. Czernin, Vienna.

[67] Schleicher, S., Kettner, C., Köppl, A., Anzinger, B., Cemper, B., Türk, A. and Karner, A. (2011) Analysis of Options to Move Beyond 20 Percent Greenhouse Gas Emission Reductions. Policy Brief addressing the EC Communication on More Ambitious Greenhouse Gas Reductions. Vienna.

[68] Hermann, A.T., Bauer, A., Pregernig, M., Reinecke, S., Hogl, K. and Pistorius, T. (2012) Die Interaktion von Wissenschaft und Politik in der österreichischen Klimapolitik. Vienna.

[69] Federal Ministry of Agriculture Forestry Environment and Water (2007) Nationaler Zuteilungsplan für Osterreich gemäß § 11 Emissionszertifikategesetz für die Periode 2008-2012. Zur Übermittlung an die Europäische Kommission im Einklang mit Art. 9 der Richtlinie 2003/87/EG. Vienna.

[70] European Commission (2007) Commission Decision of 7 July 2004 Concerning the National Allocation Plan for the Allocation of Greenhouse Gas Emission Allowances Notified by Austria in Accordance with Directive 2003/87/EC of the European Parliament and of the Council. C(2004) 2515/3 Final.

[71] Federal Government of Austria (2011) Bundesgesetz zur Einhaltung von Höchstmengen von Treibhausgasemissionen und zur Erarbeitung von wirksamen Maßnahmen zum Klimaschutz (Klimaschutzgesetz-KSG) [Government Bill].

[72] Katzmair, H., Weissengruber, S., Formayer, H., Schlatzer, M., Rosenberger, M., Artner, S., Brand, U., Groiß-Madlmair, B., Wissen, M., Pawloff, A., Mayer, E. and Neu, U. (2013) Klimapolitik in Österreich. Rolle und Einfluss klimaskeptischer Argumente in der Klimadiskussion. Vienna.

[73] Brand, U. and Wissen, M. (2012) Global Environmental Politics and the Imperial Mode of Living: Articulations of State-Capital Relations in the Multiple Crisis. Globalizations, 9, 547-560.

http://dx.doi.org/10.1080/14747731.2012.699928 